\title{
U.S. Companies in Argentina: Trade and Investment Patterns (1890-1930)
}

\begin{abstract}
Argentina was viewed as the least Americanized country in Latin America at the beginning of the twentieth century. However, the role U.S. companies in shaping the Argentinean economy in the first decades of the twentieth century has not yet been fully documented. For this reason, this article provides a new estimate of the scope and characteristics of U.S. interests in Argentina, and try to explain the role and impact of U.S. firms in Argentina's economic growth to 1930. It proposes that the impact of U.S. investments on the Argentinean economy was of longer standing and more widely diversified than has generally been assumed.
\end{abstract}

Keywords: Foreign Investment; Multinationals; Argentina; United States; First Global Economy

Argentina was viewed as the least Americanized country in Latin America at the beginning of the twentieth century. At that time, Britain, and other European nations, had heavily invested in Argentina, one of the wealthiest countries in the world with a GDP more than twice the average for Latin America (Madison 1997, 27). By 1900 about 80 percent of the foreign investment in Argentina was British (Regalsky 1986).

Corresponding author: e-mail: alluch@ conicet.gov.ar

Received 16 Feb 2018 - Accepted 12 Jun 2018

This is an Open Access article distributed under the terms of the Creative Commons Attribution-Non-Commercial-No Derivatives License (http://creativecommons.org/licenses/by-nc-nd/4.0/), which permits non-comercial re-use and distribution, provided the original work is properly cited, and is not altered or transformed in any way. 
However, the role U.S. companies in shaping the Argentinean economy in the first decades of the twentieth century has not yet been fully documented.

The case of Argentina is particularly interesting; while the country did not receive U.S. direct investment in traditional sectors, such as agriculture and mining. ${ }^{1}$ The U.S. nevertheless invested more heavily in its manufacturing and trading companies than in any other Latin American nation by 1929. In fact, in manufacturing, Argentina was followed by Brazil and Cuba. $^{2}$ The imports from the U.S. to Argentina were modest at the end of nineteenth century, yet by 1930, Argentina was the 6th largest worldwide market for U.S. goods and was the largest Latin American single purchaser of American products during the years 1927 to 1930 (See Table 1$)^{3}$

How did this process unfold, and what role did American multinational companies play in it? Using firms as analytical units, I examine which U.S. firms arrived in Argentina and when, what reasons led them to establish or acquire sales offices or factories, and how they strengthened their business position. The purpose is to provide a new estimate of the scope and characteristics of U.S. interests in Argentina, and try to explain the role and impact of U.S. firms in Argentina's economic growth to 1930. Until now, the literature focusing on U.S. companies is sparse, except for some studies on the transport, meatpacking, and petroleum

\footnotetext{
${ }^{1}$ Prior to 1929, the U.S. Department of Commerce reports had lumped together direct and portfolio investment, private and governmental, and those in separate countries. The figures for numbers of firms and book values for 1929 were organized by broad categories. Of course, book values give a highly arbitrary and understated view of real values. Argentina. See Estimates of United States direct foreign investment, 1929-1943 and 1947 (1976).

${ }^{2}$ For Latin America, see O’Brien (1996, 1999), although Argentina is hardly mentioned in his analysis. For Argentina, a classical reference is Regalsky (1986). A recent overview in Lanciotti and Lluch (2018).

${ }^{3}$ Estimated from: Our world trade; value and volume of principal exports and imports between United States and chief foreign markets (Foreign Commerce Department, Chamber of commerce of the United States [19201940]).
} 
sectors. $^{4}$ Other studies have focused on political economy and international relationships. ${ }^{5}$ Previous estimates therefore do exist, but they are incomplete or mainly concentrated on the 1930s and on industrial enterprises. In this regard, the proposition here is that research about U.S. companies is still lacking.

Before 1930, the U.S. certainly invested less capital in Argentina than did European countries, particularly Great Britain. However, based on a new quantitative estimate of U.S. companies operating in Argentina, the article proposes that the impact of U.S. investments on the Argentinean economy was of longer standing and more widely diversified than has generally been assumed. An earlier and gradual increase in the number of newly established U.S. companies since the beginning of the twentieth century cannot be measured in terms of flows of direct investment. The convergence between arrivals of new firms and U.S. direct investment flows only occurred at the end of the 1920s. The U.S. stake prevailed in the industrial sector and was significant in the commercial and service sectors. In addition, and beyond the competition between European countries and the U.S. for the Argentinean market, and especially the Anglo-American rivalry, the paper proposed that the U.S, and Great Britain have played a relatively complementary rather a competitive role as suppliers of goods, since American firms had promoted a dormant demand for many new products as a result of its technological leadership.

\footnotetext{
4 For Argentina, see Ferrer (1964), and García Heras (1985), among others. A useful study for understanding the subject is Phelps (1939). Other approaches to the problem of foreign investments (especially American) in Argentina from a political perspective can be found in Fuchs (1959) and Sommi (1949). A recent contribution for Uruguay, is Jacob (2016).

5 The literature on the economic relations between the United States and Argentina abounds, particularly from the point of view of commercial and international relations. Classical references are McGann (1957); Peterson (1964); Escudé (1983); Tulchin (1990); and Rapoport (1981).
} 
This new estimation relies heavily on empirical research, organized in a database of U.S. corporations operating in Argentina from about 1890 until 1930 (See the main sources used in the Appendix). This information complements and supplements data provided by a new database of foreign-controlled companies operating in Argentina (Foreign Companies in Argentina Database - Database FCAD-PICT 2010/0501) factoring in variables such as country of origin, creation date, organizational form, core business, capital invested/share capital, and entry strategies. The Database FCAD contains detailed information about foreign companies operating in Argentina by selected years. ${ }^{6}$ The paper also links American firms' arrival cycles to available statistics on direct investment and trade volumes between both countries. Several other contemporary historical sources have been used to illustrate the characteristics of U.S. multinational corporations (MNCs; here defined as firms that control income-generating assets in more than one country at a time) settling in Argentina. However, multinationals not only make foreign direct investments, but also transfer over borders an entire business package that includes products, processes, experience, reputation, knowledge, financing, marketing knowhow, trademarks, technology research, information, and managerial expertise (Jones 1998; Wilkins 1998; Chandler and Maszlish 2005).

The essay has six sections. The first outlines the characteristics of U.S. direct investment gathered from a newly created listing of U.S. companies established in Argentina. The second presents the overall investments' timing and the main business activities developed by U.S. corporations before 1930. Sections three to five consider the main characteristics of U.S. business expansion in three different stages (before World War I, the war period, and the

\footnotetext{
${ }^{6}$ See http://empexargentina.com/en/
} 
1920s). Section six discusses the various motivations that led U.S. firms to migrate to Argentina.

\section{U.S. companies operating in Argentina}

The conventional wisdom regarding U.S. direct investment is that most U.S. companies established in Argentina were related to the assembly of consumer goods. ${ }^{7}$ But this statement, though true, is incomplete. This research highlights the great diversity of U.S. companies operating in Argentina. It also shows the number of individual companies within each sector. Companies in the petroleum, metals and mining products, chemical and pharmaceutical, and electrical and non-electrical machinery sectors were most numerous, followed by those in manufacturing and consumer products, and banking and financial services. Meatpacking companies, agricultural machinery, and automobile companies dominated the domestic market, even if they were few in number.

The new estimate shows that previous research underestimated the number of agricultural and raw material firms; trade-supporting firms such as shipping firms; utilities; contracting firms; companies in professional, information, and financial activities; and sales organizations and manufacturing or partial-processing branches.

A distinct feature of U.S. companies in Argentina during this period was that sales extensions of U.S. corporations were initially branches of a U.S. incorporated company, in contrast to American firms' experience in Europe, where U.S. industrialists usually incorporated their sales subsidiaries in the host country because of the tax situation, local legislation, and to protect the

\footnotetext{
${ }^{7}$ Dunn (1926) and Winkler (1929) described the complexity of American interests in the first decades of the twentieth century but only partially. Phelps (1939) is an exception and represents an indispensable reference regarding industrial companies migrating to Argentina.
} 
parent company from liability (Dickens 1930; Wilkins 1970, 193). Therefore, the organization of "domestic" companies was not the norm in Argentina until the 1920s.

Table 1. US Companies by main sectors

\begin{tabular}{|l|c|}
\hline \multicolumn{1}{|c|}{ Sector } & Firms \\
\hline Petroleum, Chemical and other industrial products & 24 \\
\hline Office suppliers and electrical machinery & 23 \\
\hline Agricultural and Pastoral Products & 15 \\
\hline Manufactured and consumer products & 15 \\
\hline Banking and financial services & 12 \\
\hline Pharmaceutical and medicinal products & 11 \\
\hline Insurance companies & 8 \\
\hline Engineering and Construction & 6 \\
\hline Moving Pictures & 6 \\
\hline Service (others) & 5 \\
\hline Communications and Electricity Co (only Americans) & 7 \\
\hline Transport sector & 4 \\
\hline Agricultural Machinery & 5 \\
\hline Car companies & 4 \\
\hline Meat packing & 4 \\
\hline Miscellaneous & 14 \\
\hline N/A & 7 \\
\hline US Importers \& Representations & 19 \\
\hline Public Utilities companies (Argentinean) & 15 \\
\hline Not confirmed data & 24 \\
\hline Other companies registered as Argentinean Corporations & 12 \\
\hline
\end{tabular}

Source: Own elaboration. See Sources in the Appendix.

As suggested by Lluch and Lanciotti, the Argentinization of foreign assets became noteworthy only after 1930, and particularly after 1933, in a new economic and political milieu, when the vast majority of U.S. companies migrating to Argentina were organized as limited liability corporations (Sociedad Anónima Argentina) and incorporated under the laws of the Argentine Republic (Lanciotti and Lluch 2015a). 


\section{Overall U.S. Investments' Timing}

Before 1890, almost all foreign companies operating in Argentina were British. Not many U.S. citizens were prominent in Argentina's commercial life ${ }^{8}$ However, the proposition here is that the U.S. stake in Argentina, although quantitatively low in terms of foreign direct investments, was of longer standing than has been generally assumed. ${ }^{9}$ Based on the analysis of U.S. multinational companies' entry dynamics, it is possible to argue an ongoing and steady rise in the number of U.S. companies that settled in Argentina in the beginning of the twentieth century. It is worth noting how rapidly U.S. manufacturers entered the Argentinean market before 1913. A growth not interrupted by World War I. In fact, an important number of U.S. companies decided to start operating in the country during the war and the immediate postwar years. The 1920s were a period of consolidation and steady expansion. As shown by Lluch and Lanciotti, this is not a unique trait of U.S.'s investors. Indeed, after the World War I, the entry of foreign firms grew more than in any other period. By 1930, the number of foreign firms in Argentina had doubled the number registered in pre-war years (Lanciotti and Lluch 2015b). The migration cycle by type of business until 1930 (in both manufacturing firms and nonmanufacturing enterprises such as transportation, retailers, construction firms, advertising agencies, and credit companies) was a complex phenomenon. But on the whole, more than 50 percent of the companies started operations before the 1920s. The rest were established in

\footnotetext{
${ }^{8}$ See for example: Reports of the commission appointed under an act of Congress approved July 7, 1884, to ascertain and report upon the best modes of securing more intimate international and commercial relations between the United States and the several countries of Central and South America Commission to Central and South American States, 1884-1885 (1886).

${ }^{9}$ Exceptions to this could be found in Wythe (1949) and Wilkins (1970, chapter 9)
} 
Argentina between 1920 and $1930 .{ }^{10}$ This is coincident with the data provided by the FCADPICT 2010/0501, since only considering U.S. companies operating in the 1930 year, $42 \%$ of them have established before the 1920s.

Table 2. Annual Distribution of US companies' migration, Argentina, c.1890-1930

\begin{tabular}{|l|c|c|c|c|}
\hline & US Firms & $\begin{array}{c}\text { US } \\
\text { Importers }\end{array}$ & Total & $\begin{array}{c}\text { Share within total for } \\
\mathbf{1 8 9 0 - 1 9 3 0}(\%)\end{array}$ \\
\hline until 1900 & 6 & - & 6 & 3 \\
\hline $1901 / 1910$ & 17 & 4 & 21 & 11 \\
\hline $1911 / 1915$ & 30 & 2 & 32 & 23 \\
\hline $1916 / 1920$ & 37 & 6 & 43 & 21 \\
\hline $1921 / 1925$ & 36 & 3 & 39 & 1 \\
\hline $1926 / 1930$ & 43 & 3 & 46 & 100 \\
\hline n/a & 1 & 1 & 2 & 189 \\
\hline Total & 170 & 19 & & \\
\hline
\end{tabular}

Source: Own elaboration. See Sources in the Appendix

This data verifies two hypotheses: that there was a gradual, incremental increase in the number of newly settled companies during the first decades of the twentieth century (which cannot be measured in terms of the amount of direct investment) and that the U.S. stake in Argentina was early and remarkably diverse. The following sections, in chronological order, identify the main activities of U.S. companies in Argentina in each of the three phases previously identified.

\section{U.S. Companies before World War I}

Argentina was a vast country of fertile prairies, and it was swiftly included in global markets as a staple producer. Its successful economic performance during the first global economy was

\footnotetext{
${ }^{10}$ This calculation includes twenty-two import companies formed as foreign companies.
} 
supported, as mentioned before, by the arrival of foreign investments in infrastructure -mainly railways and ports- and services to export primary goods. Another characteristic of the Argentinean economic structure was the enormous volume of its foreign trade. The trade between the United States and Argentina developed slowly during the nineteenth century. Continental Europe (50 percent) and Great Britain (35 percent) dominated imports at the beginning of the twentieth century. ${ }^{11}$ In 1904 , U.S. sales to Argentina made their first large jump. Agricultural implements accounted for the largest single increase, followed by wood and wood manufacturers. In 1905, the most important products were timber (in bulk), vehicles and railway material, and agricultural tools and machinery. Trade between the U.S. and Argentina reached a new peak in 1910, when the country received more than half- -54 percent — of U.S. exports to South America (by value) (U.S. Department of Commerce 1900-1920).

The United States had gained an unquestionably strong position as the supplier of certain products (machinery, petroleum, agricultural equipment, lumber, and barbed wire) before World War I. American exports grew remarkably while the U.S. stake in Argentina was minimal, as stated above. For example, of the total foreign investments in Argentina in 1913, it was estimated that about 53 percent was British, 27 percent French, 10 percent German, six percent Belgian, three percent Spanish, and about only one percent American. ${ }^{12}$ Before 1910, trade was more important than the nationality of direct investment for the simple reason that half of the imported goods from the United States had a competitive advantage over similar imported European goods (McCrae, van Metre, and Eder 1931). The other half of imports from

\footnotetext{
${ }^{11}$ A contemporary study of commercial relations between the U.S. and Argentina, in Phelps (1938).

${ }^{12}$ By 1913, the stock of long-term private foreign investment reached half of the value of the total fixed capital stock. See United Nations, Economic Commission for Latin America (1958). For a general analysis of foreign investments in Argentina, see Barbero and Regalsky (2002) and Jorge (1971).
} 
the United States (pharmaceutical and chemical products, electrical machinery, textiles, iron and steel products, paper products, building materials, and tires and inner tubes, among others) faced European competition, which helps to explain the importance of having several U.S. distribution and selling organizations in Argentina to manage the substantial increase in imported U.S. goods at the beginning of the twentieth century.

The first U.S. firms that migrated to Argentina were insurance and credit reporting companies. New York Life Insurance and Equitable Life Assurance were active in Argentina's market at the end of the nineteenth century. The arrival of G. Dun \& Co. in 1902 stands as a landmark of the internalization of credit report services. The Buenos Aires office was G. Dun \& Co.'s third branch in Latin America, and its region included not only Argentina but also Paraguay and Uruguay. G. Dun \& Co.'s new strategy was to collect information about Argentinean companies and the Argentine economy for U.S. multinational and exporting companies that had initiated the process of expanding into the South American market (Vose 1916, 166).

Agricultural machinery companies also arrived in the late nineteenth century, opening direct selling and servicing branches. In 1885, J. I. Case expanded its activities to South America, appointing W. R. Grace \& Co. as distributor for the West Coast. By 1890, Case's branch office opened in Buenos Aires, becoming the first branch of a U.S. company in this industry ever established in Argentina. Other companies, such as Avery Plow Co., International Harvester Co., and Rumely Products Company opened their commercial branches (with different commercial success in each case) before World War I. During this period, in nearly all categories of agricultural machines American products provided from 70 to 99 percent of the total imports to Argentina, according to some estimates (Motz 1916). The strategy of organizing a sales branch implied a higher investment and risk than indirect representation (through 
commercial agents), but the drawbacks were outweighed by the improvement in distribution methods and after-sales services.

Before World War I, the best-known U.S. industrial investments were the meatpacking plants. In 1907, Swift \& Co., the largest US meatpacker, bought the largest plant in Argentina, the meat lockers of La Plata Cold Storage Co. The second step in U.S. penetration was the purchase of the Argentine meatpacking plant La Blanca by the National Packing Company, later controlled by Armour and Morris. ${ }^{13}$ By 1914, Sulzerberger \& Sons (later Wilson \& Co.) had a packing plant in Buenos Aires province. These U.S. companies purchased existing plants, which they improved and enlarged. With the exception of the Cudahy Packing Co., all the largest U.S. meatpackers invested in South America.

The reason that U.S. companies migrated to Argentina was to continue the chilled-beef trade with the United Kingdom. There were two reasons for this. First, available domestic surplus was diminishing. Second, Argentine beef had become competitive because US production costs had risen and Argentina was able to produce good quality beef cattle more cheaply than any other country (White 1945; Wilkins 1970). U.S. packers already faced competition in the British market: in 1905, the quantity of Argentine beef arriving in the United Kingdom exceeded that from the U.S. for the first time. Improvements to refrigeration techniques after 1900 enabled the export of chilled meat, a more perishable product. Argentina became the first country to export both frozen and chilled meat, and there were firms that handled both products (Perren 1978). As such, U.S. firms expanded Argentine chilled beef exports but by no means initiated these. Overall, these firms' migration to Argentina (and South America in general) was a

\footnotetext{
13 The National Packing Company was a combination of Swift, Morris, and Armour. When the company was liquidated in 1912 to avoid a civil suit, Swift withdrew from La Blanca and it became a property of Armour and Morris. See Hanson (1938).
} 
defensive strategy. From 1910 to 1913, between 40 and 50 percent of total Argentine beef exports came from plants owned by U.S. companies. The dominance of U.S. companies, in particular from Swift and Armour, was further extended in the following years. ${ }^{14}$

Oil companies, such as the two Standard Oil subsidiaries - Galena Signal Oil Co. and the West India Oil Co._- accounted for an important increase of trade figures. In 1909 and 1911, these companies organized their own marketing offices in Argentina. Their presence allowed U.S. interests to dominate Argentina's petroleum sector during this period, and by 1912 the U.S. handle more than 96 percent of the imports of unrefined naphtha (Solberg 1979).

In a complementary way, several companies involved with intermediate goods and consumer goods arrived in Argentina before 1914. American mass-production industries built sales organizations and branch offices. In 1900, General Electric Co. organized the South American Electric Supply Co. under the laws of the State of New York to sell its electrical apparatus and supplies in Argentina, Chile, Paraguay, Uruguay, and Bolivia (Danvers 1901). The other two of the first multinational investments were the commercial branches of United Shoe Machinery Corporation (in 1903) and Singer Sewing Machine (in 1905). Companies that sold new products, such as the Remington Typewriter Co. (1911) and National Cash Register (1913), also moved into the country. Among other multinationals that had opened import, sales, and service branches in Argentina by 1913 were U.S. Steel Co., Pullman Standard Car Export Co., and National Paper and Type Co.

\footnotetext{
${ }^{14}$ In 1914 , the South American Meat Importers' Freight Committee (as it was called in the UK) reserved and allocated the tonnage for the transportation of refrigerated Argentinean meat to Great Britain in the following terms: United States (58.50\%), United Kingdom (29.64\%) and Argentina (11.86\%). (Liceaga 1952). For an analysis of the Argentine meat trade, see Smith (1969).
} 
Previous analyses based solely on direct investment amounts do not reveal the true features characterizing the first stage of U.S. business penetration in Argentina's market. American multinationals' subsidiaries played a key role in the growth of trade between both nations. Indeed, during the first stage, competitiveness was the reason why some U.S. companies established a presence in Argentina despite the significant deficiencies in U.S. banking and communication infrastructure and facilities in Argentina (compared with European competitors such as Great Britain). ${ }^{15}$ In addition, political and opportunity parameters contributed to increase Argentina's attractiveness (Wilkins 1994). Both the national and local government policies were very favorable to all foreign investors (U.S. included). At the same time, Argentina's growing internal market combined with the lack of local competition (except for the banking sector) provided ample opportunities for multinationals (Lanciotti and Lluch 2015a).

\section{U.S. Companies during the Wartime Period}

By the outbreak of World War I, U.S. business interests had permeated a wide section of activities. The Argentinean case confirmed that the First World War did nothing to impede the expansion of American business investments abroad (Wilkins 1970). Furthermore, wartime dislocations deepened the shallow channels of trade between Argentina and the United States. The eclipse of Germany — the United States' principal competitor in "modern" manufactured goods- forced the Argentines to turn more and more to the United States. The U.S. exports trade, even in a depressed market, was able to double its share from 12.8 percent to 32.2 percent

\footnotetext{
15 As Lincoln Hutchinson stated in his report about Trade Conditions in South America, "American banks are conspicuous by their absence." See Hutchinson (1906). American exports also suffered serious delays and the uncertainty of return cargoes. For a review of shipping facilities at this time See Whelpley $(1911,35)$.
} 
between 1914 and 1917 (See Table 3). In that sense, the war accentuated and accelerated a development that would have occurred more gradually. This trend was accompanied by an increase in the number of registered foreign companies. Even if during the war the flows of direct investment almost ceased (by its value), an important number of U.S. companies still decided to start operating in Argentina.

During the early period, U.S. businesspeople had confronted in Argentina the inadequacy of its business infrastructure. For years, they had relied on British financial institutions, cable companies, and ships for banking transactions, communications, and transport, but World War I underscored the necessity of improving and developing their own business infrastructure. As a part of this process, U.S. bank branches began to be established during these years. The U.S. Federal Reserve Act of 1913, Section 25, of which first authorized the establishment of U.S. bank branches in foreign countries and U.S. dependencies, became effective in 1914, and the National City Bank of New York was the first to use this authorization in South America. The bank had begun studying the argentine banking situation in 1908-urged on by U.S. ambassador to Argentina Charles H. Sherrill and encouraged by the U.S. State Departmentand had obtained a thorough knowledge of Argentina by $1913 .{ }^{16}$

The first foreign branch of the National City Bank was finally opened in Buenos Aires in November 1914. It was also the first branch of any nationally chartered U.S. bank. A bank official reported that the decision to open branches in South America was reached not on the basis of estimated outlay and return, but on the basis of whether or not U.S. business interests

\footnotetext{
${ }^{16}$ Until the passage of the Federal Reserve Act, American national banks were prohibited from establishing foreign branches and from making acceptances. See Phelps (1927) for an analysis of the foreign expansion of American banks. About the National City Bank of New York expansion, see Cleveland and Huertas (1985) and Wilkins (1974, 19-23). Also see Mayer (1973, 60-76).
} 
would find these banking facilities of great help and value in extending business relations. The branch opened with only eight employees. The first manager was J. H. Allen who was the manager of the Banque Nationale de la République d'Haïti. The selection was made under the consideration that he was acquainted with Latin American banking methods as well as those of the U.S. (Cleveland and Huertas 1985, 78). ${ }^{17}$ The immediate aim was modest: to perform the usual banking functions, to foster the bank's relations with corporate customers, and to provide auxiliary banking services such as credit and trade information. Despite the low expectations, the Buenos Aires branch began to make a profit almost immediately. Within one year of its inauguration, the branch had accumulated enough deposits to become the eighth largest depository in Argentina. By 1917, the branch had become Argentina's ninth-largest bank. In 1917, First National Bank of Boston arrived in Argentina and opened its first foreign branch (Mayer 1973).

In the manufacturing sector, Ford Co. took the initiative, establishing a sales office in 1914, and in 1917 the company built an assembly plant. In 1916 the U.S. was already the source of 80 percent of the automobiles imported into Argentina; a few years earlier, in 1912, only 24 percent of imports were from the U.S. Kodak was another multinational that migrated during these years, which opened its first commercial branch in Buenos Aires in 1915. In the tire industry, sales subsidiaries of Goodyear, Firestone, and U.S. Rubber were established between 1915 and 1917. Since the World War I, Argentina became the best market for U.S. rubber in the Southern Hemisphere (up to 75 percent of exports headed to Latin America went to Argentina). All of

\footnotetext{
${ }^{17}$ See also The Americas 1, no. 1 (1919, 12-13). According to Mayer (1973, 66), the president of the United States Steel Corporation, James A. Farrel, wanted an American bank to finance him in Argentina. He asked Vanderlip to open the first National City Bank branch in Argentina, pledging the support of the giant steel trust in return. He also promised to obtain the deposits of International Harvester, Armour and Swift, in addition to those of his own company for the National City Bank.
} 
the products consumed in the market were foreign-made since the first local commercial tire plants were set up only in the early 1930s by Goodyear and Firestone.

A clear sign that U.S. interests had grown during World War I was the organization of AmCham (American Chamber of Commerce in Argentina) in 1918. Its purpose was to improve the relations between American sellers and Argentine and South American buyers. The Chamber was an outgrowth of the American Commercial Club, and it was supported by big multinationals. AmCham had 74 founding members, including the majority of banks, manufacturers, importers, and exporters who were settled in Argentina at that time (Chamber of Commerce of the United States 1920). ${ }^{18}$

To sum up, during World War I more effective banking and communications systems between the United States and Argentina were established, strengthening the U.S. competitive position in the local market, aiding U.S. trade flows, and promoting the arrival of a new group of multinationals.

\section{U.S. Companies during the 1920s: New Products and Services}

A number of significant changes unfolded after World War I. As the Argentine domestic market expanded and diversified in a low political risk environment, it attracted more foreign direct investment. The U.S. took on the role of main supplier of external capital to Latin America formerly occupied by Europe, and by the end of the 1920s, the U.S. capital flows exceeded the British ones (Grosse 1989, 10). ${ }^{19}$

\footnotetext{
${ }^{18}$ Chamber of Commerce of the United States of America in the Argentine Republic (1920).

${ }^{19}$ A very large part (perhaps as much as $80 \%$ ) of the increase in U.S. investments in Latin America between 1919 and 1930 was in the form of publicly floated bonds of governments and the bonds and stocks of private corporations. Argentina was one of the chief governmental borrowers during the early part of the 1920s.
} 
The period after World War I marked the end of a FDI cycle that had focused on the exploitation of natural resources. New firms moved into the country, and the companies already installed there enlarged their facilities. As Lewis has pointed out, the increased foreign demand for American exports boosted the funds available for investment abroad. The result was a steady and rapid increase in America's foreign holdings. ${ }^{20}$ The Department of Commerce at the end of 1924 estimated that the total of US investments in Argentina was 121 millions (Halsey and Butler 1925). As a consequence, in the 1920s, the United States confirmed its supremacy in investment flows and trade (See Table 3).

In 1925, U.S. exporters gained from Great Britain first place among Argentina's merchandise suppliers. In 1929, U.S. exporters provided 26.3 percent of Argentinean imports, while Great Britain supplied 17.6 percent. Argentina was the United States' largest single purchaser in Latin American between 1927 and 1930. Durable goods represented a significant portion of this trade. In the 1920s, U.S. imports moved towards new products resulting from technological pioneering, such as automobiles (including accessories), agricultural machinery, and office and household appliances. These new products were the most important in terms of values of goods shipped to Argentina from the U.S., accounting for 50 percent in 1922, for example (by value). The shares commanded by these new products, along with fuels and machinery, explain why imports from the United States grew four times in the 1920s, while products coming from continental Europe failed to double their volume and imports from the United Kingdom increased by less than 40 percent (Jorge 1971; Caputo de Astelarra 1984).

\footnotetext{
${ }^{20}$ By 1929, the principal area in which American business enterprises invested funds was South America (followed by Canada and Europe). The three areas altogether account for roughly three-fourths of American private investment abroad. See Lewis $(1938,424)$.
} 
Table 3. Argentine - U.S. Trade (Years 1913-1930)

\begin{tabular}{|c|c|c|c|c|c|c|c|}
\hline Year & M from US & \% of M & X to US & \% of X & Trade with & \% of total & $\begin{array}{c}\text { Arg. Trade } \\
\text { Balance }\end{array}$ \\
\hline 1913 & 165938 & 14,7 & 55884 & 4,7 & 221822 & 9,6 & -110054 \\
\hline 1914 & 98881 & 13,5 & 112428 & 12,3 & 211309 & 12,8 & 13547 \\
\hline 1915 & 171795 & 24,8 & 212968 & 15 & 384763 & 19,2 & 41173 \\
\hline 1916 & 243156 & 29,1 & 272114 & 20,8 & 515270 & 24,2 & 28958 \\
\hline 1917 & 313829 & 36,4 & 366524 & 29,4 & 680353 & 32,2 & 52695 \\
\hline 1918 & 384243 & 34,3 & 375345 & 20,7 & 760588 & 25,8 & -8898 \\
\hline 1919 & 529246 & 35,5 & 429924 & 17,4 & 959170 & 25 & -99322 \\
\hline 1920 & 705444 & 33,1 & 350308 & 14,9 & 105752 & 22,5 & -355136 \\
\hline 1921 & 456501 & 26,9 & 134603 & 8,8 & 591104 & 18,4 & -321898 \\
\hline 1922 & 346812 & 22,2 & 181339 & 11,8 & 528151 & 17 & -165473 \\
\hline 1923 & 412311 & 20,9 & 204131 & 11,7 & 616442 & 16,5 & -208180 \\
\hline 1924 & 415163 & 22,7 & 163273 & 7,1 & 578436 & 13,8 & -251890 \\
\hline 1925 & 468788 & 23,9 & 162961 & 8,2 & 631531 & 15,9 & -305827 \\
\hline 1926 & 460924 & 24,6 & 163961 & 9,1 & 624885 & 17 & -296963 \\
\hline 1927 & 495037 & 25,4 & 190499 & 8,3 & 685536 & 16,2 & -304538 \\
\hline 1928 & 441205 & 23,2 & 198335 & 8,3 & 639540 & 14,9 & -242870 \\
\hline 1929 & 516307 & 26,3 & 212633 & 9,8 & 728940 & 17,6 & -303674 \\
\hline 1930 & 370723 & 22 & 135110 & 9,7 & 505833 & 16,4 & -235613 \\
\hline
\end{tabular}

Note: Figures show 000 in real values (values in Argentinean Pesos). M (imports), X (exports).

Source: Adaptation from information compiled in Trade relations between Argentina and the United States of America (Buenos Aires, Chamber of Commerce of the U.S. of America in the Argentine Republic, 1946).

British concern for the rising American share as Argentina's industrial supplier while the U.K. remained its leading commodity buyer heightened the business rivalry between both nations. Nonetheless, regardless of the Anglo-American rivalry debate, at the end of the 1920s, in 18 out of 25 listed products imported to Argentina there was no real competition between the U.S. and Great Britain (McCrae, et. al. 1931). This situation was even recognized by the British government: "A good proportion of the trade of each country comprises goods in which the other cannot, for certain fundamental reasons effectively compete at the present time, such as in agricultural machinery, automobiles, petroleum products, lumber, hinder twine, newsprint, cinematograph films, oil.” (Great Britain 1923, 20). The U.S. had not only replaced European 
producers in the Argentine market in some categories but most importantly had promoted a dormant demand for many new products in many sectors..

The rate of new U.S. companies established in Argentina reached its peak in the 1920s, but did not take over the first position in the total of foreign firms until much later, as shown by Lluch and Lanciotti (2015a). For the first time, the migration of US companies was, coupled with a historical record in direct investments. The United States became the major supplier of new capital in Argentina during the 1920s. ${ }^{21}$ The U.S. Department of Commerce estimated that at the end of 1924, the total of U.S. investments in Argentina was \$121 million. By 1929, it was calculated that U.S. firms had invested $\$ 331$ million. ${ }^{22}$

In terms of amount and value, the most substantial impact in Argentina of U.S. investment toward the end of the 1920s was made by public utility companies; from \$1.5 million in 1924 to $\$ 147$ million in 1929 . This sharp increase was part of a worldwide trend: the same happened in European and other Latin American countries. Paralleling the domestic boom, U.S. corporations made sizable new foreign investments in communications and in power and light (Lanciotti 2008; see also Wilkins 1974, 129). Purchases by the International Telephone and Telegraph Company (ITT) placed the major Argentine telephone companies under U.S. ownership. The firm began its expansion in March 1928 by securing a controlling share in the Argentine Telephone Co. of Buenos Aires. Early in 1929, it bought the United River Plate Telephone Company (Compañía Unión Telefónica del Río de la Plata). This company, established by Britain in 1882, was the most important company of its kind in Argentina and it

\footnotetext{
${ }^{21}$ Between 1914 and 1919, the dollar value of U.S. investments in Latin America increased by half and more than doubled in the decade following 1919. See United Nations $(1955,7)$.

${ }^{22}$ See Estimates of United States Direct Foreign Investment, 1929-1943 and 1947 (New York, 1976) and Halsey and Butler (1925).
} 
was the biggest telephone enterprise of South America (Great Britain 1931, 87). In the electrical sector, the American \& Foreign Power Co. (a controlling affiliate of Electric Bond and Share Company) and the Intercontinents Power Co. (formed in 1928) were the only two U.S. corporations that purchased Argentine electrical power stations. The largest transaction occurred in 1929 when the Electric Bond and Share Company took control of the Atlas Light and Power Company of London, the chief British electrical interest in Argentina. Between mid1928 and November 1929, the two U.S. firms added about 140 power stations to the forty they already owned (Great Britain 1930, 35). The apparent mass transfer of British properties to U.S. ownership worried the British community in Argentina. The British Ambassador in Argentina, Sir Malcolm Robertson, was disturbed by the American purchase of British-owned utilities in South America and he apparently feared that their railways, too, "would fall into Yankee hands." 23

By 1929, as have been said, Argentina was the first choice for manufacturing in all of Latin America, followed by Brazil and Cuba (which got half the investment Argentina received) (See Table 4). ${ }^{24}$

It is difficult to quantify the amount of capital that foreign companies invested in Argentina but the role of U.S. companies in certain industries and products was highly significant. In addition, by the 1920s, the American businessman community had consolidated itself in Argentina with the active participation of American businessmen in the AmCham (around 80 per cent of total

\footnotetext{
${ }^{23}$ Peterson $(1964,356)$. For a specific analysis of the Anglo-U.S. trade rivalry in Argentina, see Gravil (1975).

${ }^{24}$ The figures for numbers of firms and book values for 1929 were organized by broad categories. Book values give a highly arbitrary and understated view of real values. See Estimates of United States Direct Foreign Investment, 1929-1943 and 1947 (American Business Abroad) (1976).
} 
U.S. firms were associated), other social organizations and clubs, and publications, such as The American Weekly of Buenos Aires (Lanciotti and Lluch 2018).

Table 4: American Direct Investment in Argentina, 1929 (values in Thousands of dollars)

\begin{tabular}{lcl}
\hline & Number & Value \\
\hline Manufacturing & 27 & 82008 \\
Distribution (a) & 37 & 52908 \\
Agriculture & 8 & 29811 \\
Public utilities and transportation & 7 & 147836 \\
Miscellaneous (b) & 20 & 19256 \\
\hline
\end{tabular}

Notes: a) Petroleum is included in Distribution, b) Mining and smelting is included with Miscellaneous. Source: Estimates of United States direct foreign investment, 1929-1943 and 1947 (New York, Arno Press, 1976).

Source: Own elaboration

U.S. industrial firms took a leading position in some sectors and made a partial contributing to local industrial growth. ${ }^{25}$ During the period from 1926 to 1930 , forty-five new companies established subsidiaries in Argentina. Meanwhile, some other industrial companies already established enlarged their capacity. Such was the case with the Argentine Portland Cement Co. and the Otis Elevator Co., which extended its operations in 1927 by opening a factory in Buenos Aires to manufacture elevators (Ferrer 1964, 205).

Ford continued to dominate the Argentinean market during this period (60 percent of the 4,071 automobiles imported by Argentina in January 1925 were Fords, and 58 percent of the remainder were divided among four other U.S. companies) (Phoebus 1926, 19). By the mid1920s, U.S. car companies were practically the only suppliers. General Motors opened its Argentinean assembly plant in 1925 as part of a worldwide strategy. ${ }^{26}$ Competition was

\footnotetext{
${ }^{25}$ For an analysis of the industrial sector, see Barbero and Rocchi (2003).

${ }^{26}$ Between 1925 and 1928 it increased its capital as much as four times (from 5 million to 20 million Argentine pesos), History and Activities of the North American Colonies of Argentina (1929).
} 
extremely keen, not only among the big U.S. automakers but also among more than fifty other firms (Brady 1923; Tewksbury 1929).

In patent medicines and medical specialties, U.S. expansion was notable, even though France accounted for 50 percent of the imports of prepared medicines by 1925 (Bergin 1927, 12). Many firms including Sidney Ross Co. Inc. (as an Argentinean Liability Company); Lanman \& Kemp Inc.; William R. Warner \& Co.; Scott y Browne Inc. of Argentina; Cia Scholl SA; Colgate/Palmolive Int. Co.; Dorothy Gray \& Co.; and Parke Davis \& Co. opened sales branches in Buenos Aires, manufacturing on a small scale and packaging locally mostly to avoid custom duties. The chemical sector followed the same process, although its worldwide expansion took place later and its market-oriented stake in South America was smaller than its stakes in Europe and Canada (Wilkins 1974, 84). ${ }^{27}$

U.S. film studios were established during these years also. By 1926, Argentina was the United States' largest Latin American market (and fourth-largest market worldwide of films for local consumption) in terms of number of films imported. Every renowned U.S. producer and distributor was locally represented: Metro-Goldwyn-Mayer, Paramount Pictures, Universal Pictures Corporation, Fox Film Corporation, United Artists, among others (North 1926, 1045). About 85 percent of the pictures shown in Buenos Aires during the 1920s were made in the United States (Phoebus 1926, 36).

The expansion of U.S. interests was noticeable in other sectors, beyond public utilities and manufacturing and partial-processing activities (including assembly operations). Of course, U.S. firms stayed away from the sectors in which British companies were operating, such as banking and railways. But the 1920s witnessed the arrival of commercial and consumer finance

\footnotetext{
${ }^{27}$ Argentina was an important market for U.S. chemicals ( $1^{\text {st }}$ in Latin America, $7^{\text {th }}$ in the U.S. world markets).
} 
companies, most of which financed exports of automobiles and other consumer goods (radios, electric appliances, and furniture). These companies in the financial sector helped to reinforce the U.S. market share of durable goods.

U.S. companies from the transportation, construction, and engineering sectors also consolidated their presence in Argentina in the late 1920s. For example, Warren Brothers Company of Argentina, a paving contractor, was organized in 1925, attracted by the increasing development of road construction and paving in the city of Buenos Aires. In advertising, in 1929, J. Walter Thompson (JWT) migrated to Argentina thanks to a strategic alliance with General Motors, which was trying to capture overseas markets for its products. A momentary edge over its closest competitor, Ford Motor Co., gave GM the push it needed to launch an overseas offensive (another example of the multiplier effect of U.S. direct investment). From 1929 on, the JWT experts provided an important service to U.S. firms, developing advertising campaigns and consumer preference polls for corporate clients (Salvatore 2005).

The largest sector (by number) of new firms arriving into Argentina was direct selling and trading companies. This is coincident with data provided by the Database FCAD-PICT 2010/0501. Still, in 1930, 43 U.S. firms classified by activity were listed under G category (this means involved in the commercialization and distribution of products). American companies dominated the sector (considering all foreign companies in Argentina).

The creation of selling organizations was a key strategy to encourage the penetration of foreign capital. As worldwide, trading houses spurred its growth. Behind the development of selling organizations the interest was placed in the development of distribution networks of the same nationality. However, the importance of sales organizations has not received much attention in previous FDI studies. By 1929, half of the U.S. sales organizations of Latin America were based 
in the city of Buenos Aires. ${ }^{28}$ The significant number of such firms in Argentina was a result of previous efforts by U.S. companies to develop distribution networks. If by 1916 most goods of U.S. origin sold in Argentina were in the hands of the British and other foreign importers, the situation was different in the 1920s since several American houses had been established to handle practically every line of goods.

A complementary issue, even less studied in the international business literature, is the role of U.S. multinationals acting as representatives of other U.S. interests. A directory of U.S. companies represented in Argentina showed that the branches of multinational companies not only specialized in producing and marketing their own goods but also represented and imported related products. From a total of 509 U.S. companies represented in 1933, 109 had direct representation in the country. But one-third (133 firms) of the four hundred remaining firms were represented only by three U.S. multinational branches, as Table 6 shows: United Shoe Machinery Co. Arg. (sixty-eight companies), General Electric SA (thirty-seven companies), and Cia Standard Electric Argentina (twenty-eight companies). The list of main distributors of U.S. products in Argentina also included Westinghouse Int. SA (twelve), General Electric Appliances SA (nine), National Lead Co. (eight), and the U.S. Steel Products Co. (six).

For example, General Electric Co. (GE Co.), in addition to organizing special departments for the sale of various classes of electrical devices and materials, established an industrial section that specialized in importing and selling machines and devices to be used in construction industry. Acting as representatives of U.S. companies, these multinationals were supplying their own products but also complementary goods. U.S. Shoe Machinery Co, which manufactured

\footnotetext{
${ }^{28}$ U.S. investment in Africa, Asia, and Oceania altogether amounted to $\$ 72$ million, whereas in Australia and New Zealand it reached $\$ 22$ million. In Canada, the value of selling organizations was estimated at \$37 million. In Europe the amount was $\$ 132$ million (Dickens 1930, 23).
} 
industrial machinery for shoe manufacture, imported its own products as well as related products for distribution-brushes from Baker Brush Co., New York; cork filler from Keno Supply Company; buttons for boots and shoes from Federal Button Co.; and so on. These companies also provided services and technical support.

Table 5. Main distributors of U.S. products in Argentina, 1933

\begin{tabular}{|c|c|c|}
\hline Name & $\begin{array}{l}\text { Number of } \\
\text { representations }\end{array}$ & Status \\
\hline United Shoe Machinery. Co. Arg. & 68 & branch of U.S. company \\
\hline General Electric SA & 37 & branch of U.S. company \\
\hline Cia Standard Electr Arg & 28 & branch of U.S. company \\
\hline Will Smith, S. & 27 & Importers \& Representations \\
\hline Mayón Limitada & 23 & $\begin{array}{l}\text { Importers \& Representations, No } \\
\text { Amcham Associate }\end{array}$ \\
\hline H W Peabody \& Cia, Arg & 14 & Importers \& Representations \\
\hline Cia Westinghouse Int SA & 12 & branch of U.S. company \\
\hline CIA La Carmona & 10 & $\begin{array}{l}\text { Importers \& Representations, No } \\
\text { Amcham Associate }\end{array}$ \\
\hline Storer \& Co. & 9 & Importers \& Representations \\
\hline Los fabricantes Unidos Inc & 9 & Importers \& Representations \\
\hline General Electric Appliances SA & 9 & branch of U.S. company \\
\hline National Lead Co SA & 8 & branch of U.S. company \\
\hline Cereal Machine Co Ltd & 8 & branch, Importers \& Representations \\
\hline The Armco Int Co & 7 & branch of U.S. company \\
\hline $\begin{array}{l}\text { Johns Manville Boley Ltda (organized } \\
\text { in 1931) }\end{array}$ & 7 & Importers \& Representations \\
\hline Arthur S Hawtrey & 7 & Importers \& Representations \\
\hline U.S. Steel Products Co & 6 & branch of U.S. company \\
\hline P. B. Borwne \& Co & 6 & $\begin{array}{l}\text { Importers \& Representations, No } \\
\text { Amcham Associate }\end{array}$ \\
\hline O. Hidalgo & 6 & $\begin{array}{l}\text { Importers \& Representations, No } \\
\text { Amcham Associate }\end{array}$ \\
\hline Leng Roberts \& Co & 6 & $\begin{array}{l}\text { Importers \& Representations, No } \\
\text { Amcham Associate }\end{array}$ \\
\hline Arturo W. Boote \& Co. & 6 & $\begin{array}{l}\text { Importers \& Representations, No } \\
\text { Amcham Associate }\end{array}$ \\
\hline
\end{tabular}

Source: Guide to American Companies in Argentina, Represented by Members of the Chamber" published in Comments on Argentine trade, 3 October 1933, Buenos Aires. 
The hybridization of forms adopted by U.S. interests (through various combinations of manufacturing, distributing, and representing) was notorious. One explanation for this hybridization is that U.S. companies needed to improve economies of scale and take advantage of opportunities to expand their import trade business. Another hypothesis is the importance of strengthened cooperation and personal relationships among U.S. businesspeople. The need for U.S. distributors for U.S. goods in foreign markets was commonly discussed in official and business publications, and, ideally, U.S. business representatives were expected to be "American in heart, body and soul." (U.S. Federal Trade Commission 1916, 1919; AmCham $1919,2)$ By founding their own sales agencies and avoiding having to use the services of established commercial houses (particularly British ones), the United States was little by little destroying an important European advantage and, in that way, helping to strengthen U.S. trade and investment flows to Argentina.

\section{Why Did U.S. Companies Settle in Argentina?}

Theories of the multinational enterprise suggest that foreign direct investment must be explained at different levels (Dunning 1993; Jones 1998, 436; among others). A number of ownership-specific advantages mainly at financial, managerial, entrepreneurial, and technological levels was key to the success of U.S. multinationals in Argentina. Some companies, such as meat-packing plants, had technical, marketing and financial advantages over some British and local competitors. In addition, the meatpacking plants, as well as other mineral and raw material extractive and processing industries, such as Standard Oil and the National Lead Company, and companies that processed bones, hides, and corn, were the United States' main supply-oriented investments. 
In the Argentinean case, several location-specific advantages were crucial to understanding the causes of migration. These factors include market size, income level, and potential growth. In the 1920s the Argentinean market represented approximately 50 percent of the activity of the entire South American subcontinent. ${ }^{29}$ In that sense, Wilkins's opportunity parameters serve also to explain the entry of new US companies into Argentina in the 1920s.

According to internationalization-transaction cost theory, the kind of goods to be produced and commercialized also determines the motivation to invest abroad (Williamson 1985). The tendency to construct their own distribution networks and not to depend on intermediaries was associated with brand name goods that had some of these features: complex distribution; special design (the goods' production required specialized knowledge); high price per unit; after-sales service; competition; and a strong brand presence and advertising of goods to create new markets. U.S. companies justified the beginning of direct operations in the country by promising more direct control of distribution, cost reductions, increased availability of products, adaptation of products to consumer demand, as well as to overcome differences in customs regulations, language and other cultural aspects. In some business sectors, rather than competing with Argentina's local industry, U.S. firms competed with other foreign interests or among themselves. Reducing costs and improving marketing facilities helped to increase sales and to promote U.S. trade names.

The creation of a dense distribution network and an aggressive advertising campaign were also key to the success of several U.S. companies (Sanger 1920, 14; see also Bulletin of the Chamber of Commerce of the U.S. in the Argentine Republic 1920, 3). One example can be found in the strategy of some agricultural machinery manufacturers, who efficiently adapted their products

\footnotetext{
${ }^{29}$ In 1921, Argentina was defined as "the most lucrative and certainly the most competitive market in South America" (Klein 1921, 12).
} 
to local use; in addition, they innovated in distribution methods and after-sales services (Motz 1916). Similarly, U.S. automobiles dominated the market due to their low cost, durability, and lightweight—important attributes, given Argentina's bad roads. "Following sales with service" was Ford's slogan. ${ }^{30}$ According to U.S. analysts, U.S. supremacy in the Argentine automobile market did not necessarily stem from the advantage the United States gained during World War I. The sales points were price and service (Beecroft 1917; Tewksbury 1929).

An essential factor in promoting more direct dealing between manufacturer and importer was the increase in sales of products that require service. For example, U.S. drug manufacturers developed their own sales organizations and advertising campaigns, which allowed them to obtain a better share of a market dominated by French companies (Great Britain 1930, 54). By the late 1920s, when patterns of consumption were undergoing enormous change in Argentina, U.S. companies made a crucial contribution to this process. Generally speaking, there was a rise in consumer demand in a new environment permeated by local industrial growth and secularization and influenced by the rise of new business practices — such as advertising — that reshaped the market and the patterns of marketing (Rocchi 1998; 2006).

High tariffs and taxation also stimulated industrial migration to Argentina, particularly for some items, although it should be noted that their impact was low until the Great Depression set in. Prior to 1930, only some items were affected by local merchandise classifications, or higher tariffs on a product imported in packaged form than on the same product imported in bulk. For example, pharmaceutical companies imported certain items in bulk and packaged them within the market to avoid tariffs. Another case was the tariff advantages provided by the importation of unassembled products. At the late 1920s, the Argentine tariff provided for a 30 percent

\footnotetext{
${ }^{30}$ The American Weekly 1, no. 3 (21 July 1923, 12).
} 
concession on unassembled automotive units and a 15 percent reduction on semi-assembled units. As a consequence, Ford and General Motors assembled motor vehicles partly in Argentina (cheaper cars were assembled there entirely) (Wythe 1949, 119). For tire companies such as Goodyear and Firestone, the greatest incentive to produce locally was the differential in duties between finished casing and crude rubber, after 1930. In a competitive situation, this could mean virtual exclusion for those firms not assembling locally. ${ }^{31}$

The process of company migration, as said before, was gradual. Although each case was unique, the settling of foreign companies followed a similar pattern. Most migrations began with indirect representation (through independent agents, commission houses, or a salaried export manager) followed by direct representation. The next step was opening branch sales offices and finally, in some cases, starting assembly manufacturing plants that first combined importation and in situ manufacturing and later specialized in manufacturing. When their business volume and profit grew, the large U.S.-based trading enterprises saw advantages in having their own foreign houses (United States Federal Trade Commission 1916; see also Wilkins 1970).

As they also did in other countries, U.S. concerns deliberately established sales and distribution agencies before they undertook assembly or manufacturing (Dunning 1998, 17). For example, farm implement maker B. F. Avery \& Sons used the services of a local importer for more than 30 years, and in 1911 it decided to improve the sale and services of its products and opened a branch house in Buenos Aires, establishing direct factory-to-consumer service in Argentina. It was particularly important for U.S. companies to adapt their products to meet the requirements

\footnotetext{
${ }^{31}$ Although no tires were manufactured in Argentina before 1930, the relatively high duties and the increasing demand have made various tire companies considered establishing subsidiary factories. In 1931 the Firestone Tire \& Rubber Co was opened with a capacity of 1000 tires and rubbers per day. On changing tariffs and the implications for manufacturing firms, see Lewis (1987). See also Phelps (1939, 67).
} 
of the host countries. By 1929, when Argentina was the second largest market worldwide for agricultural implements, practically all of the 150 different types of farm equipment imported into Argentina by B. F. Avery \& Sons were special "South American models."32

The U.S. experience in Argentina conforms to the normally accepted progression of selling: first agents, then sales branches, then secondary assembly/manufacturing, and that manufacturing activities included different methods. By 1930, however, full local manufacturing by U.S. firms was far from complete and few companies had achieved complete production, since practically all companies produced parts or changed the form of the product in some manner. Most firms had not moved far beyond secondary manufacture, and they were focused principally on packing, assembly, and service for products, without risking the resources needed for a complete production facility.

To sum up, the steady expansion of U.S. business interests may be attributed to international conditions, the growth of Argentinean consumers' purchasing power as well as their ready acceptance of "new products." The internal market attractiveness and political and opportunity parameters contributed to Argentina's attractiveness. Both the national and local government policies were very favorable to foreign investors. In addition, the expanding economy and the demand for required industrial and commercial investment services attracted entrepreneurial initiatives in the banking, transport, insurance, and advertising sectors, among others. U.S. firms in service sectors established units in the region to hold the loyalty of their domestic customers. Inducements to invest were diverse, and included the multiplier effect of multinational expansion (acting as a driving force) and a desire to expand into South America generally, using Argentinean subsidiaries as staging areas.

\footnotetext{
${ }^{32}$ History and Activities of the North American Colonies of Argentina (1929, 42).
} 


\section{Conclusions}

This essay has intended to complement and review prior studies about American companies in Argentina, using the firm as the unit of analysis. The results of the new estimation show that American firms' migration cycles were gradual and the U.S. stake dated from earlier than traditionally assumed. The investment's flows were not affected by the deglobalization shift during World War I or afterward. On the contrary, the U.S. experience contributes to consolidate the view that Argentina was a low-risk and growing host economy, very open to foreign investments and stable both economically during this period (Lanciotti and Lluch 2015a).

The U.S. firms' time of arrival and activities did not always coincide with the amount of U.S. direct investments. New firm arrivals and U.S. direct investment flows only converged in the late 1920s. Most American companies preferred greenfield investments and did not set up joint ventures, partnerships, and alliances with local companies. By 1929, then, the United States had become the dominant new investor in Argentina, with an extensive and complex business network.

Another distinctive characteristic of U.S.-based companies settling in Argentina, as compared to those moving into other Latin American countries, was that they ran a large number of operations, excluding land and agricultural sectors (as shown in Table 4). Indeed, within the scope of American firms' worldwide foreign investment strategy, Argentina was not fully involved in "supply-oriented strategies," as were the majority of other Latin American countries, with the major exception of meat-packing plants. Argentina was viewed as an outlet for technology exports and other consumer and intermediate goods, and a remarkably diverse range of activities and services were carried out for U.S. companies. The Argentine experience 
should be considered as an intermediate case for U.S. companies' strategies around the world, presenting certain similarities with some European countries.

U.S. investments significantly influenced Argentina's economy. The competitive advantages of the largest American multinationals, with their modern manufacturing, marketing, and management methods, explained the dominance of the United States in several sectors (Chandler 1977; 1990). U.S. firms had not only replaced European producers in some areas of the Argentine market but also created a demand for new goods. These companies helped diversify the domestic market's structure, particularly as a result of their new techniques in distribution, marketing, and advertising. They also contributed to innovation processes in the early stages of Argentina's industrialization. However, their impact would be more limited than in other countries, as full manufacturing by U.S. firms was far from complete by 1930 .

At the same time, the penetration of U.S. firms brought some negative effects for the Argentine economy. The United States' involvement in nontraditional business sectors created new forms of dependence through machinery and assembly part imports. After World War I, Argentina imported fewer consumer goods and more durable goods and machinery. This trend clearly favored U.S. manufacturers. Conversely, the non-complementary nature of the two economies as well as U.S. tariff policies reducing raw-material imports and establishing sanitary embargoes restricted Argentina's purchasing power. ${ }^{33}$ The result was a trade imbalance that grew continuously (except during World War I) and peaked in 1929, after being partly mitigated in the 1920s by the net inflow of U.S. capital (Table 4). Nonetheless, while those dollar investments made the U.S. the single most important foreign influence on Argentina's

\footnotetext{
${ }^{33}$ In 1926, the Department of Agriculture prohibited the importation of Argentine grapes and refrigerated meats after January 1927.
} 
economy, they increased Argentine commercial deficits with the United States, since U.S. direct investment increased imports. The structural trade imbalance between Argentina and the United States was correlated in part with the trade behavior of U.S. multinationals. ${ }^{34}$ A complex scenario characterized U.S.-Argentine trade relations in the late 1920s, although until then U.S. firms had been able to take advantage of Argentina's economic openness and successful integration to the global economy.

\section{References}

AmCham. 1919. Comments on Argentine Trade 1 (1) (20 Aug.): 2.

American Business Abroad. 1976. Estimates of United States direct foreign investment, 1929-1943 and 1947. New York: Arno Press.

Barbero, María Inés, and Andrés Regalsky. 2002. "Las inversiones extranjeras y el comercio exterior." In Nueva Historia de la Nación Argentina, edited by Academia Nacional de la Historia, vol. 9. Buenos Aires: Planeta.

Barbero, María Inés, and Fernando Rocchi. 2003. "Industry and Industrialization in Argentina in the Long Run: From its Origins to the 1970s." In The New Economic History of Argentina, edited by Geraldo Della Paolera, and Alan Taylor, 261-294. Cambridge, UK: Cambridge University Press.

Beecroft, David. 1917. Argentine Market for Motor Vehicles. Miscellaneous series, no. 62. Washington: Government Print. off.

Bergin, Mary 1927. Markets for Prepared Medicines. United States. Bureau of Foreign and Domestic Commerce (Dept. of Commerce) (Trade promotion series, no. 48). Washington: Government Print. Off.

Brady, G. S. 1923. Argentine Markets for Motor Vehicles. Washington: Government Print Off.

Caputo de Astelarra, Sara. 1984. "La Argentina y la rivalidad comercial entre los Estados Unidos e Inglaterra (1899-1929).” Desarrollo Económico 23 (92): 589-608.

\footnotetext{
${ }^{34}$ At the same time, Great Britain remained Argentina's principal customer originating a triangular payment: Europe bought Argentine products and the U.S. received payment from Europe. About the triangular aspect of Argentine trade, see Fodor and O'Connell (1973).
} 
Chamber of Commerce of the United States of America. Our world trade; value and volume of principal exports and imports between United States and chief foreign markets. Washington, DC: Foreign commerce department, Chamber of Commerce of the United States. (1920-1940) Baker Library, Historical Collection.

Chamber of Commerce of the U.S. in the Argentine Republic.1920. "Distribution in Argentina." Bulletin of the Chamber of Commerce of the U.S. in the Argentine Republic 1 (12): 3.

Chandler Jr., Alfred D. 1977. The Visible Hand: The Managerial Revolution in American Business. Cambridge, Mass.: The Belknap Press of Harvard University Press.

Chandler Jr., Alfred D. 1990. Scale and Scope: The Dynamics of Industrial Capitalism. Cambridge, Mass: Belknap Press of Harvard University.

Chandler Jr., Alfred D., and Bruce Mazlish, eds. 2005. Leviathans: Multinational Corporations and the New Global History. Cambridge, UK, New York: Cambridge University Press.

Cleveland, H., and Thomas F. Huertas 1985. Citibank, 1812-1970. Harvard studies in business history, 37. Cambridge, Mass.: Harvard University Press.

Danvers, Ernesto. 1901. John Grant \& Son's Directory of the British, Anglo-Argentine and North American residents in the Argentine Republic and Argentine commercial guide. Buenos Aires: John Grant \& Son.

Dickens, Paul. 1930. American Direct Investments in Foreign Countries, 1929. Washington, DC.

Dunn, Robert. 1926. American foreign investments. New York: Viking Press.

Dunning, John. 1993. Multinational Enterprises and the Global Economy. Wokingham: AddisonWesley.

Dunning, John. 1998. American Investment in British Manufacturing Industry (Rev. and updated ed.). London, and New York: Routledge.

Escudé, Carlos. 1983. Gran Bretaña, Estados Unidos y la declinación argentina, 1942-1949. Buenos Aires: Editorial de Belgrano.

Ferrer, James. 1964. "U.S.-Argentine Economic Relations, 1900-1930." PhD diss., University of California, Berkeley.

Fodor, Jorge, and Arturo O’Connell. 1973. 'La Argentina y la economía atlántica en la primera mitad del siglo XX." Desarrollo Económico 13 (49): 3-65.

Fuchs, Jaime. 1959. La penetración de los trusts yanquis en la Argentina. Buenos Aires: Cartago.

García Heras, Raúl. 1985. Automotores norteamericanos, caminos y modernización urbana en la Argentina, 1918-1939. Buenos Aires: Libros de Hispanoamérica. 
Gravil, Roger. 1975. “Anglo-U.S. Trade Rivalry in Argentina and the D’Abernon Mission of 1929.” In Argentina in the Twentieth Century, edited by David Rock, 41-65. Pittsburgh: University of Pittsburgh Press.

Great Britain. 1923. Report on the Financial, Commercial, and Economic Conditions of the Argentine Republic.

Great Britain. 1930. Economic Conditions in the Argentine Republic.

Great Britain. 1931. Economic Conditions in the Argentine Republic.

Grosse, Robert. 1989. Multinationals in Latin America. London, New York: Routledge.

Halsey, Frederic and Sherwell Butler. 1925. Investments in Latin America. Washington: Finance and investment division. United States Department of Commerce, Bureau of Foreign and Domestic Commerce.

Hanson, Simon. 1938. Argentine meat and the British market: chapters in the history of the Argentine meat industry. California: Stanford University Press, and London: H. Milford, Oxford University Press.

Herald 1929. History and activities of the North American colonies of Argentina: Commemorating the visit of Mr. Herbert Clark Hoover, President-elect of the United States, to Argentina (1929). Buenos Aires: Buenos Aires Herald.

Hutchinson, Lincoln. 1906. Report on Trade Conditions in Argentina, Paraguay, and Uruguay. Washington: Government. Print. Off.

Jacob, Raúl. 2016. Las inversiones norteamericanas, 1900-1945. Montevideo: Objeto Directo.

Jones, Geoffrey. 2005. Multinationals and Global Capitalism: From the Nineteenth to the Twenty-First Century. Oxford: Oxford University Press.

Jorge, Eduardo. 1971. Industria y concentración económica. Buenos Aires: Siglo XXI.

Klein, Julius. 1921. "The competitive situation in South American Trade." The Review of Economic Statistics 3 (1): 11-18.

Lanciotti, Norma. 2008. "Foreign Investments in Electric Utilities: A Comparative Analysis of Belgian and American Companies in Argentina, 1890-1960." Business History Review 82 (Autumn): 503-28.

Lanciotti, Norma, and Andrea Lluch. 2015a. "Investing in growing markets: Opportunities and challenges for multinationals in Argentina, 1900-1960.” Management \& Organizational History 10 (2): 1-17.

Lanciotti, Norma, and Andrea Lluch. 2015b. "Las grandes empresas extranjeras en la Argentina: características y transformaciones entre 1913 y 1960.” [Large Foreign Companies in Argentina] 
Characteristics and Transformations between 1913 and 1960] Investigaciones de Historia Económica 11 (2): 184-195. doi: doi.org/10.1016/j.ihe.2014.09.002.

Lanciotti, Norma, and Andrea Lluch. 2018. Empresas Extranjeras en Argentina desde el Siglo XIX al Siglo XXI. Buenos Aires: Imago Mundi.

Lanciotti, Norma S., and Andrea Lluch. 2018. "Staffing policies and human resource management in Argentina: American and British firms (1890-1930s)". Business History DOI: $\underline{10.1080 / 00076791.2018 .1471061}$

Lewis, Cleona. 1938. America's stake in international investments. Washington, DC: The Brookings Institution.

Lewis, Colin. 1987. "Immigrant Entrepreneurs, Manufacturing and industrial Policy in the Argentine, 1922-1928." Journal of Imperial and Commonwealth History 16 (1): 77-108.

Liceaga, José. 1952. Las carnes en la economía argentina. Buenos Aires: Raigal.

Maddison, Angus. 1997. La economía mundial, 1820-1992. Análisis y Estadísticas. Madrid: OCDE.

Mayer, Robert. 1973. "The Origins of the American Banking Empire in Latin America: Frank A. Vanderlip and the National City Bank." Journal of Interamerican Studies and World Affairs 15 (1), Special Issue on Foreign Investment and Dependence in Latin America: 60-76.

McCrae, Roswell C., Thurman W. Van Metre, and George Jackson Eder. 1931. International Competition in the Trade of Argentina. Worcester, Mass.: Carnegie Endowment for International Peace, Division of Intercourse and Education.

McGann, Thomas. 1957. Argentina, the United States, and the Inter-American System, 1880-1914. Cambridge, Mass.: Harvard University Press.

Motz, Frank, and United States. Bureau of Foreign Domestic Commerce. 1916. Markets for Agricultural Implements and Machinery in Argentina Washington, DC: Government Print. Off.

North, C. J. 1926. "Our Foreign Trade in Motion Pictures," Annals of the American Academy of Political and Social Science 128:104-5.

O’Brien, Thomas F. 1996. The Revolutionary Mission: American Enterprise in Latin America, 19001945. New York: Cambridge University Press.

O'Brien, Thomas. 1999. The Century of U.S. Capitalism in Latin America. Albuquerque: University of New Mexico Press.

Perren, Richard. 1978. The meat trade in Britain, 1840-1914. London and Boston: Routledge \& Kegan Paul.

Peterson, Harold. 1964. Argentina and the United States, 1810-1960. Albany: University of New York. Phelps, Clyde William. 1927. The Foreign Expansion of American Banks. New York: The Ronald Press Company. 
Phelps, Dudley Maynard. 1939. Migration of Industry to South America. Westport, Conn.: Greenwood Press Publishers.

Phelps, Vernon Lovell. 1938. The International Economic Position of Argentina. Philadelphia: University of Pennsylvania Press; London, H. Milford, Oxford University Press.

Phoebus, Mildred Anna. 1926. Argentine Markets for United States Goods. Washington, DC: Government Print. Off.

Rapoport, Mario. 1981. Gran Bretaña, Estados Unidos y las clases dirigentes argentinas. Buenos Aires: Editorial de Belgrano.

Regalsky, Andrés. 1986. Las inversiones extranjeras en la Argentina, 1860-1914. Buenos Aires: Centro Editor de América Latina.

Rocchi, Fernando. 1998. "Consumir es un placer: La industria y la expansión de la demanda en Buenos Aires a la vuelta del siglo pasado.” Desarrollo Económico 37 (148): 533-58.

Rocchi, Fernando. 2006. Chimneys in the Desert: industrialization in Argentina during the export boom years, 1870-1930. Stanford: Stanford University Press.

Salvatore, Ricardo. 2005. "Yankee Advertising in Buenos Aires: Reflections on Americanization." Interventions 7 (2): 216-35.

Sanger, Jesse William. 1920. Advertising Methods in Argentina, Uruguay, and Brazil, Washington, DC: Government Print. Off.

Smith, Peter. 1969. Politics and Beef in Argentina: Patterns of Conflict and Change. New York: Columbia University Press.

Solberg, Carl E. 1979. Oil and Nationalism in Argentina: A History. Stanford, California: Stanford University Press.

Sommi, Luis. 1949. Los capitales yanquis en la Argentina Buenos Aires: Monteagudo.

Tewksbury, Howard H. 1929. The Automotive Market in Argentina. Washington, Bureau of Foreign and Domestic Commerce. Trade Promotion Series, $N^{\circ} 84$, US, Washington: US Government Print. Off.

Tulchin, Joseph. 1990. Argentina and the United States: A Conflicted Relationship. Boston: Twayne Publishers.

United States, Dept. of Commerce. 1900-1920. Statistical Abstract of the United States. Washington, DC.

United States. Federal Trade Commission. 1916. Report on Cooperation in American Export Trade. United Nations. 1955. Foreign Capital in Latin America. New York: United Nations.

United Nations, Economic Commission for Latin America. 1958. El Desarrollo Económico de la Argentina. Santiago de Chile: ECLA. 


\section{Journal of Evolutionary Studies in Business}

Vose, Edward Nevile. 1916. Seventy-Five Years of R. G. Dun \& Co., the Mercantile Agency, 18411916. Brooklyn: Dun \& Co.

Whelpley, James. 1911. Trade Development in Argentina. Washington, DC: Government Print. Off.

White, Langdon. 1945. “The Argentine Meat Question.” Geographical Review 35 (4): 634-646.

Wilkins, Mira. 1970. The Emergence of Multinational Enterprise: Business Abroad from the Colonial Era to 1914. Cambridge, Mass.: Harvard University Press.

Wilkins, Mira. 1974. The Maturing of Multinational Enterprise: American Business Abroad from 1914 to 1970. Cambridge, Mass.: Harvard University Press.

Wilkins, Mira 1994. “Comparative Hosts”. Business History 36 (1): 18-50.

Wilkins, Mira. 1998. "Multinational Enterprises and Economic Change." Australian Economic History Review 38 (2): 103-34.

Williamson, Oliver. 1985. The Economic Institutions of Capitalism: Firms, Markets, Relational Contracting. New York: Free Press.

Winkler, Max. 1929. Investments of United States capital in Latin America. Boston: World Peace Foundation Pamphlets.

Wythe, George. 1949. Industry in Latin America, 2d ed. New York: Columbia University Press. 


\section{$\underline{\text { Appendix }}$}

Sources used:

- Drees, Charles. 1922. Americans in Argentina: a record of past and present activities of Americans in Argentina, Rodney to Ridle. Buenos Aires: Conti Press.

- Guide to American Companies in Argentina, Represented by Members of the Chamber. 1933.

Buenos Aires: Chamber of Commerce of the United States of America in the Argentine Republic, 1933.

- History and activities of the North American colonies of Argentina. 1929. Buenos Aires, Buenos Aires Herald.

- Hombres del día. Diccionario biográfico argentino. 1917. Buenos Aires: Sociedad Inteligencia Sud americana.

- La Información. Revista mensual Sociedades Anónimas, cooperativas, asociaciones. 19301935. Buenos Aires.

- List of Members. Chamber of Commerce of the United States of America in the Argentine Republic. Buenos Aires, Selected Years: 1920, 1930 and 1940.

- Ministerio de Justicia e Instrucción Pública. 1900-1930. Memoria. Personas Jurídicas. Buenos Aires: Ministerio de Justicia e Instrucción Pública.

- Monitor de sociedades anónimas. 1904-1931. Imprenta y Casa Editora de Coni Hnos.: Buenos Aires.

- North American directory of the Argentine and Brazil. 1927. Buenos Aires: River Plate edition.

- North American directory of the Argentine and Brazil. 1921. Buenos Aires: River Plate edition.

- U.S. Trade Directory, American Business in Argentina. 1969. Buenos Aires: Chamber of Commerce of the United States of America in the Argentine Republic.

This is an Open Access article distributed under the terms of the Creative Commons Attribution-Non-Commercial-No Derivatives License (http://creativecommons.org/licenses/by-nc-nd/4.0/), which permits non-comercial re-use and distribution, provided the original work is properly cited, and is not altered or transformed in any way. 